\title{
GIS Based Landslide Hazard Mapping Prediction in Ulu Klang, Malaysia
}

\author{
${ }^{1,2}$ Muhammad Mukhlisin, ${ }^{1}$ Ilyias Idris, ${ }^{1}$ Al Sharif Salazar, ${ }^{1}$ Khairul Nizam \& \\ ${ }^{1}$ Mohd Raihan Taha \\ ${ }^{1}$ Department of Civil and Structural Engineering, Faculty of Engineering and Built \\ Environment, University Kebangsaan Malaysia \\ ${ }^{2}$ Department of Civil Engineering, Polytechnic Negeri Semarang, Indonesia \\ email: mmukhlis2@yahoo.com
}

\begin{abstract}
Since 1993, a number of landslides have been reported in Ulu Klang, Malaysia. These landslides caused fatalities and economic losses. Most of these landslides occurred in man-made slopes. Geographical Information System (GIS) is proposed to be used as the based machine for the production of landslide hazard map. This study highlights the area based landslide hazard assessment at Ulu Klang area using GIS application in order to help the engineer or the town planner to identify the most suitable development area besides predicting the potential landslide hazard area. Four main factors that influence of landslide occurrence were chosen include slope gradient aspect, geology, surface cover/land used and precipitation distribution. Landslide hazardous areas were analyzed and mapped using GIS application and produced a hazard map with five different indexes (i.e., very low, low, medium, high and very high hazard). The results of the analysis were verified using the landslide location data. The result showed that the model was very suitable in predicting landslide hazard and generating landslide hazard maps.
\end{abstract}

Keywords: GIS; Landslide hazard assessment; Steeplands; Ulu Klang.

\section{$1 \quad$ Introduction}

In tropical countries like Malaysia, most landslides are triggered by heavy rainfall. Landslides have posed serious threats to settlements and structures that support transportation, natural resource management and tourism. More than 100 hillslopes had been identified by Malaysian Public Works Department (PWD) as risky for possible landslides. The hillslopes are found predominantly in Fraser's Hill, Cameron Highlands, Genting Highlands (all in Pahang), Gunung Raya (Langkawi), Paya Terubung Valley (Penang), the mountain ranges in Ulu Kelang, Selangor.

The development on hill slopes area has increased in occurrence of landslides in developed areas in Malaysia. Most of the landslides that caused most damaged in Malaysia occurred in man-made slopes. Examples of such landslides include

Received October $14^{\text {th }}, 2009$, Revised June $3^{\text {rd }}, 2010$, Accepted for publication June $9^{\text {th }}, 2010$. 
the Highland Towers (1993), Taman Zooview (2006) and Bukit Antarabangsa in 2008 [1]. Landslide is one of major natural disasters in mountainous areas in Malaysia especially in Ulu Klang area. Landslides often occur particularly during the rainy season even in high-populated areas.

Recently, there were studies on landslide hazard evaluation using GIS in Malaysia (e.g., Lee and Talib, [2]; Lee and Pradhan, [3] and Huat et al, [4]). GIS technologies could provide a powerful tool to model the landslide hazards for their spatial analysis and prediction. This is because the collection, manipulation and analysis of the environmental data on landslide hazard can be done much more efficiently. Geographical Information System (GIS) has been applied to help the slope hazard assessment and analysis. GIS is a great set of tools for collecting, storing, retrieving at will, transforming and displaying spatial data from the real world for particular set of purposes. Even though some studies have been carried out using GIS in Malaysia, there is view study for analyzing landslide hazard area particularly on Ulu Kelang, where potential occurrence of landslide is quite high.

In this study four main parameters were used to analysis probability location of landslide in Ulu Klang area include slope gradient aspect, geology, surface cover/land used and precipitation distribution. For the analysis of landslide susceptibility and for the assessment of the effect of each factor, landsliderelated data have been collected and constructed to spatial database; landsliderelated factors have been extracted and overlaid; and landslide susceptibility maps have been made and verified.

\section{$2 \quad$ Method}

\subsection{Study Area}

Ulu Klang, which is, geographically located at the latitude of $3^{0} 12^{\prime} 00^{\prime}$ "North and $101^{\circ} 46^{\prime} 01^{\prime}$ longitude is under the jurisdiction of Ampang Jaya Municipality and Kajang Public Works Department. The location of Hulu Klang in the Klang Valley has increased the demand for its land. Ulu Klang is on a fast track of urbanization. As a close area from the Kuala Lumpur city, Ulu Klang have increased the demand of its land resulted in rapid increased of development and housing project in this area particularly in Klang Valley. A number of fatal landslides have been reported in Ulu Klang starting with Tragedy of Highland Tower collapse in 1993. Table 1 shows the major slope failures in Ulu Klang area from year 1993 to 2008. The main scope of works for this study is to carry out hazard assessment and produce an area based slope hazard map. 
Table 1 Major landslides in Ulu Klang area from year 1993 to 2008

\begin{tabular}{lll}
\hline No. & Date & Location of Slope Failure \\
\hline 1 & 11.12 .93 & Highland Tower \\
2 & 14.05 .99 & Bukit Antarabangsa, Ampang-Ulu Klang \\
3 & 15.05 .99 & Athanaeum Towers, Ulu Klang \\
4 & 05.10 .00 & Bukit Antarabangsa \\
5 & 29.10 .01 & Taman Zoo View, Ulu Klang \\
6 & 08.11 .01 & Taman Zoo View, Ulu Klang \\
7 & 20.11 .02 & Taman Hill View \\
8 & 02.11 .03 & Oakleaf Park Condominiums in Bukit Antarabangsa \\
9 & 07.11 .03 & Jalan Bukit Mulia, Bukit Antarabangsa, Ulu Klang \\
10 & 31.01 .05 & Jalan Tebrau in Dataran Ukay, Ulu Klang \\
11 & 01.02 .05 & Jalan Tebrau, Dataran Ukay, Ulu Klang \\
12 & 31.05 .06 & Taman Zoo View - Kg Pasir, Ulu Klang \\
13 & 06.12 .08 & Jalan Wangsa 9, Bukit Antarabangsa \\
\hline
\end{tabular}

Source: Huat et al. [4]

Hazard maps have been used all over the world to identify areas of existing and potential slope unsteadiness. Hazard maps can be developed in many ways. The methods for preparing Hazard Maps have been categorized by Hutchinson and Toledano [5] into three groups comprises of geotechnical approach, direct methods and indirect methods.

In this study both methods of direct and indirect approach are to be adopted. The method was adopted from previous study (i.e., Huat et al. [4] and Golder [6]) with some differences study parameters. According to Huat et al. [4], most landslide preparatory causal factors in Ulu Klang area (developed area) were due to human activities, lack of maintenance, design inadequacy and construction problems. These unpredicted factors require detailed field inspection and mapping. The geomorphologic map prepared from field inspection is used as calibration tools in the hazard assessment. As for the indirect methods, heuristic method is to be adopted in the study. Scores to be adopted in the factor overlay approach can be derived from the experts' survey and these will be used to classify the landslide hazards. The indirect approach is important for inaccessible areas such as forest, steep terrain and thick undergrowth.

Scores were applied on each layers based on the priority in contributing to a landslide event. The dependent model parameters (landslide contributing factors) have been identified before formulating the hazard-rating model. A landslide cause tree diagram was prepared to identify all the potential preparatory and triggering causal factors of a landslide. These geographically distributed causal factors or parameters that potentially contribute to landslides 
are referred to in this study as landslide dependent model parameters. In this study, four proposed dependent model parameters are selected as follows:

a) Slope Gradient

b) Geology

c) Land Used/ Surface Cover

d) Maximum Daily Precipitation

Table 2 The proposed dependent parameter and inter-parameter variables.
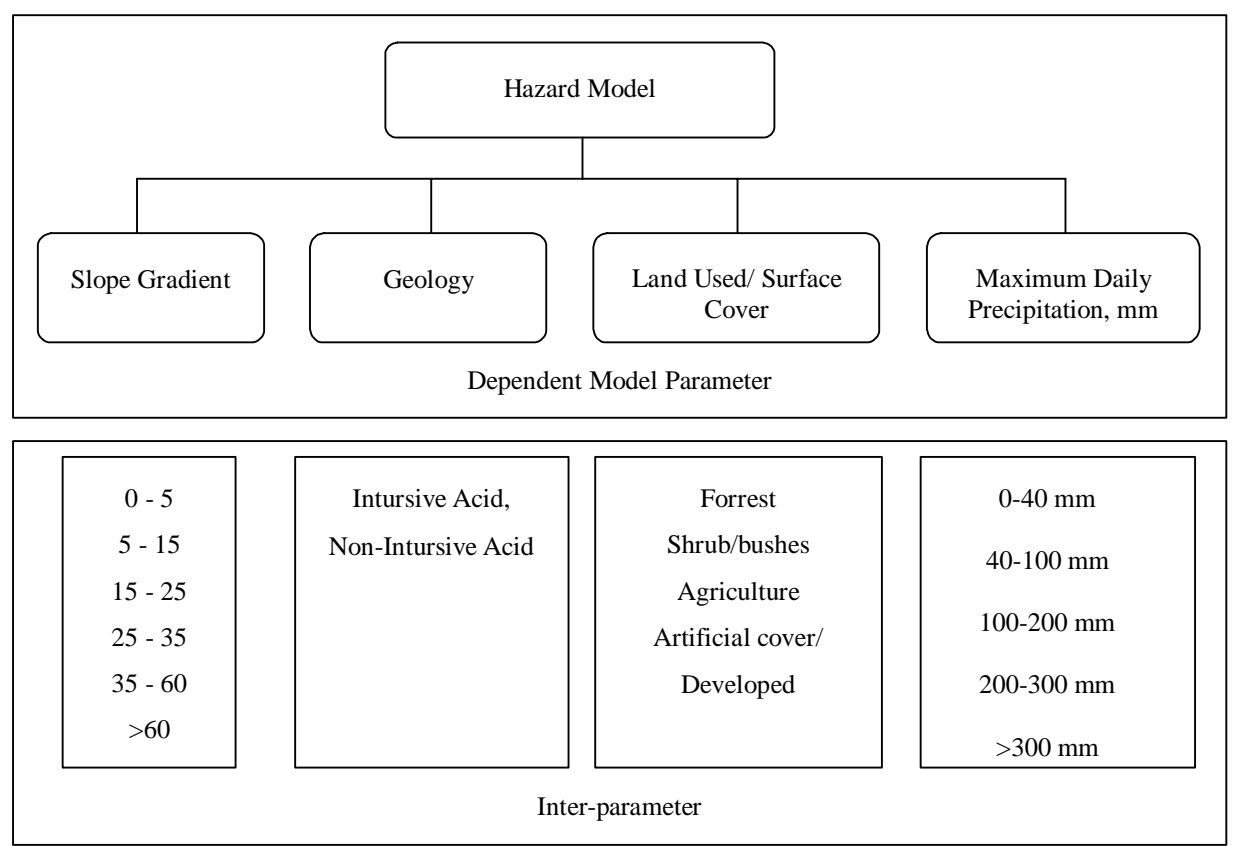

Within each model parameter, different scores are proposed to different groupings depending on their correlations with landslides. Groupings within a parameter class are referred to in this study as inter-parameter variables. Table 2 shows the proposed dependent parameter model and the respective interparameter variables.

For example, several ranges of slope angle were selected as the inter-parameter variables of the dependent model parameter of slope gradient. Scores of each inter-parameter variable were assigned with numbers based on engineering judgment of the inter-parameter variables. A high score value can be assigned to slope angle range, which is thought to have high probability of landslide. Additional inter-parameter can be included to account for strengthening 
measures such as soil nails, anchors, retaining walls and steep rock cut. This would overcome the limitation in GIS hazard ratings because in general, slopes with strengthening features are designed to be steep. Negative rating can also be adopted to eliminate confusion generated from the slope angle layer (Huat et al. [4]). Table 3 shows an example of ratings for inter parameters rating of dependent parameter model of slope gradient.

Table 3 Example of inter-parameter ratings for dependent parameter model slope gradient.

\begin{tabular}{cc}
\hline Gradient (degree) & Score \\
\hline $0-5$ & 0.3 \\
$5-15$ & 0.6 \\
$15-25$ & 0.9 \\
$25-35$ & 1.2 \\
$35-60$ & 1.6 \\
$>60$ & 2.0 \\
\hline Additional Inter-parameter & Score \\
\hline Soil nail & -3 \\
Rock Slope (discontinuities) & 1 \\
Rock Slope (continuities) & -3 \\
Rock Slope (strengthening) & -3 \\
Natural Slope & -2 \\
Anchor & -1 \\
Retaining Wall & -1 \\
No Treatment & 0 \\
\hline
\end{tabular}

\subsection{Pair Wise Comparison Method}

The scores or weightings of the possible model parameter in factor overlay method can be formulated using pair wise method. Pair wise comparison is used as a decision making tool in many applications to rank the relative importance of multiple variables (Huat et al. [4] and Golder [6]). The pair wise comparison process is proposed to derive the scores or weightings for each of the landslide dependent parameter.

The process is based on engineering judgment and compares individually:

1. The relative importance of the parameter in influencing the potential for landslides compared one against another, and

2. The degree to which each parameter is more important than each counterpart. 
The final adopted pair wise comparisons of the dependent parameter models parameter are presented in Table 4 . The outcome of the pair wise comparison was used to assign weightings to each model parameter. From the matrix in Table 4, the relative scores were calculated by summing the product of each model parameter and its relative importance rating as shown in Table 5. The total value of all the attribute weightings was taken as 1.0. The applied scores indicate the degree to which the potential for landslide is influenced by each model parameter, relative to the other parameters.

Hazard Score = WSG (VSG) + WGe (VGe) + WDP (VDP) + WSC (VSC)

Where:

WSG is the model parameter weighting for Slope Gradient WGe is the model parameter weighting for Geology.

WDP is the model parameter weighting for Daily Precipitation WSC is the model parameter weighting for Surface Cover VSG is the inter-parameter weighting for Slope Gradient VGe is the inter-parameter weighting for Geology.

VDP is the inter-parameter weighting for Daily Precipitation VSC is the inter-parameter weighting for Surface Cover.

Table 4 Pair Wise Comparison table.

\begin{tabular}{|c|c|c|c|c|c|}
\hline $\begin{array}{l}\text { Para } \\
\text { meter } \\
\text { ref. }\end{array}$ & Description & $\begin{array}{c}\text { Slope } \\
\text { Gradient } \\
\text { (A) }\end{array}$ & $\begin{array}{c}\text { Geology } \\
\text { (B) }\end{array}$ & $\begin{array}{c}\text { Daily } \\
\text { Precipitatio } \\
\text { n (C) }\end{array}$ & $\begin{array}{c}\text { Surface } \\
\text { Cover (D) }\end{array}$ \\
\hline A & Slope Gradient & - & A2 & A2 & 0.5 \\
\hline B & Geology & - & - & 0.5 & D1 \\
\hline $\mathrm{C}$ & $\begin{array}{l}\text { Daily } \\
\text { Precipitation }\end{array}$ & - & - & - & D1 \\
\hline $\mathrm{D}$ & Surface Cover & - & - & - & - \\
\hline Note: & \multicolumn{5}{|l|}{$1=$ important } \\
\hline & \multicolumn{5}{|c|}{2 = very important } \\
\hline & \multicolumn{5}{|l|}{$0.5=$ equivalent } \\
\hline
\end{tabular}

The formula for the hazard score is the sum of the products of the dependent parameter and inter-parameter scores (Table 5). From this analysis we proposed the landslide hazard formula based on four dependent parameter and interparameter score as follows:

Hazard Score $=0.5625($ VSG $)+0.0625($ VGe $)+0.3125($ VSC $)+0.0625($ VDP $)$ 
Table 5 Dependent parameter scores/weightings based on Pair-Wise Comparison.

\begin{tabular}{c|ccccc}
\hline Attribute & Parameter & Count & Sub-total & Total & Weightage \\
\hline Slope Gradient & 0.5 & 1 & 0.5 & & \\
(SG) & A1 & 0 & 0 & 4.5 & 0.5625 \\
& A2 & 2 & 4 & & \\
\hline Geology & 0.5 & 1 & 0.5 & & \\
(Ge) & B1 & 0 & 0 & 0.5 & 0.0625 \\
& B2 & 0 & 0 & & \\
\hline Daily Precipitation & 0.5 & 1 & 0.5 & & \\
(DP) & C1 & 0 & 0 & 0.5 & 0.0625 \\
& C2 & 0 & 0 & & \\
\hline Surface Cover & 0.5 & 1 & 0.5 & & \\
(SC) & D1 & 2 & 2 & 2.5 & 0.3125 \\
& D2 & 0 & 0 & & \\
\hline & \multicolumn{5}{c}{ Total } \\
\hline
\end{tabular}

Five hazard ratings, very low through very high were adopted. The hazard classes adopted in the study are:
a) Very High Hazard
b) High Hazard
c) Medium Hazard
d) Low Hazard
e) Very Low Hazard

The selection of hazard ratings is somewhat subjective. The ratings indicate the likelihood of a landslide occurring. As for this study, due to limited landslide historical records were made available during the analysis, the hazard classes were first classified by equally dividing the maximum score into 5 equal classes.

\section{$3 \quad$ Result and Discussion}

ArcGIS 9.3 needs a few of extension support such as 3D Analysis, Spatial Analysis, Analysis Tools, Raster Calculator and Global Mapper 9.03 in order to analyse and getting reliable result. Surface Analysis can be done based on DEM (Digital Elevation Model). The purpose of this analysis is to roughly identify the risky area. Surface interpolation functions make predictions from sample measurements for all conditions in a raster dataset. There are several ways to 
derive a prediction for each location. The interpolation tools are generally divided into deterministic and geostatistical methods. Topo to raster and topo to raster by file are interpolations methods designed for creating continuous surfaces from contour lines; contain properties favourable for creating surfaces for the thematic analysis. Contour data, geology data, daily precipitation data and surface cover data will be analyzed by using ArcGIS 9.3. Each parameter data will be represented by certain attribute, which is known by score/weighting. In this study scoring analysis was determined based on judgment and references from previous studies (e.g., Huat et al. [4], Singh et al. [7] and Golder [6]). Overlapping technique between layers for the parameter was made to generate map of landslide risk.

\subsection{Gradient}

A guideline from government agencies like Minerals and Geosciences Department; and Department of Town and Regional Planning stated that the degree of risky hilly area starts at 25 degree. Singh et al. [7] stated that the hilly area with gradient range from 0 to 5 degree would be scored as 0.30 . The score value will be higher when the gradient of the slope increased. The score value for every range of gradient is illustrated in Table 6.

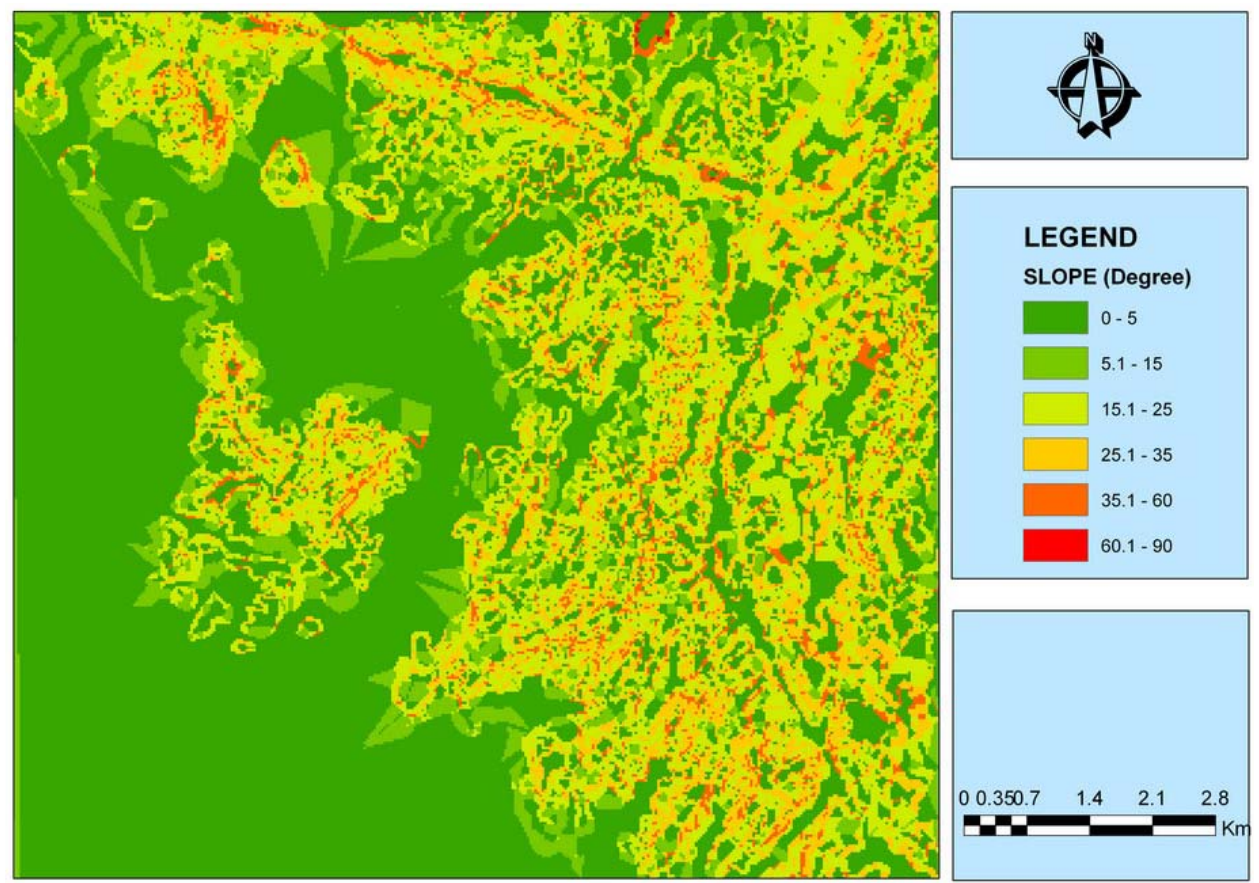

Figure 1 Result of gradient analysis from contour data. 
Table 6 Classification and score division for parameter of gradient.

\begin{tabular}{cc}
\hline Angle Gradient (degree) & Score \\
\hline $0-5$ & 0.30 \\
$5-15$ & 0.60 \\
$15-25$ & 0.90 \\
$25-35$ & 1.20 \\
$35-60$ & 1.60 \\
$>60$ & 2.00 \\
\hline
\end{tabular}

\subsection{Geology}

In this case study, rock can be classified in 2 types, namely rock of intursive acid and non-intursive acid. For the intursive acid rock, the probability occurrence of landslide is higher. It was stated that the score value for the rock is 3 and for the non-intursive acid, the value of score is 1 , as illustrated in Table 7.
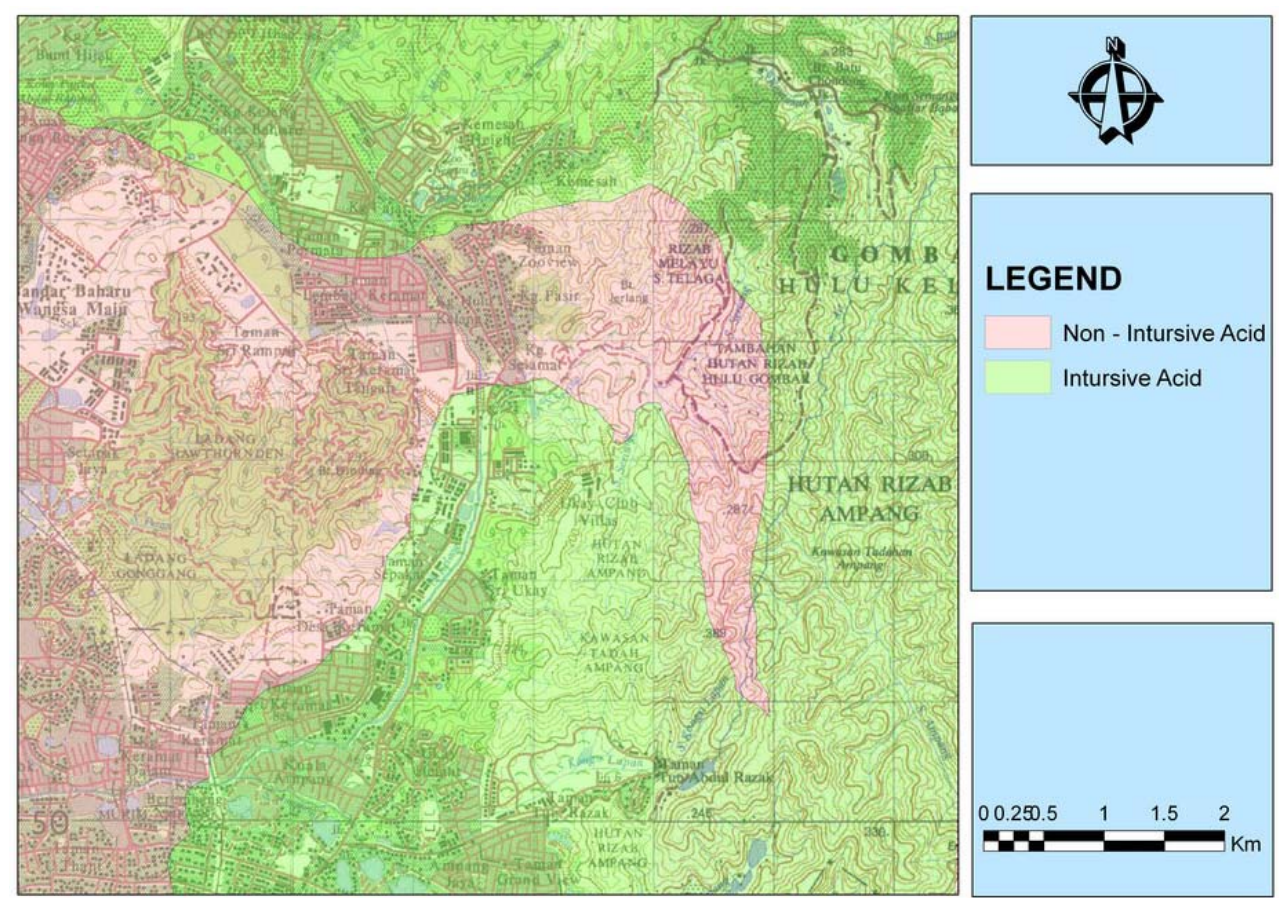

Figure 2 Type of rocks in Ulu Klang area. 
Table 7 Classification and score division for parameter of rock geology.

\begin{tabular}{cc}
\hline Rock Geology & Score \\
\hline Non-intursive acid & 1 \\
Intursive acid & 3 \\
\hline
\end{tabular}

\subsection{Maximum Daily Precipitation}

Maximum daily precipitation data can be referred from result of analysis produced by Ampang Irrigation and Drainage Department, JPS, as illustrated in Table 8. There are 3 rain observation station has been identified; Ukay Height Station (10145'36. 279’E 3¹0’23. 719’N); JPS Ampang Station (10144'53. 381'E 3`9'53. 495”N) and Genting Klang Station (10145’8. 181'E 3¹3’58. 829 ”N), as shown in Figure 3. The data will be key-in into ArcGIS9.3 software for analysis purpose.
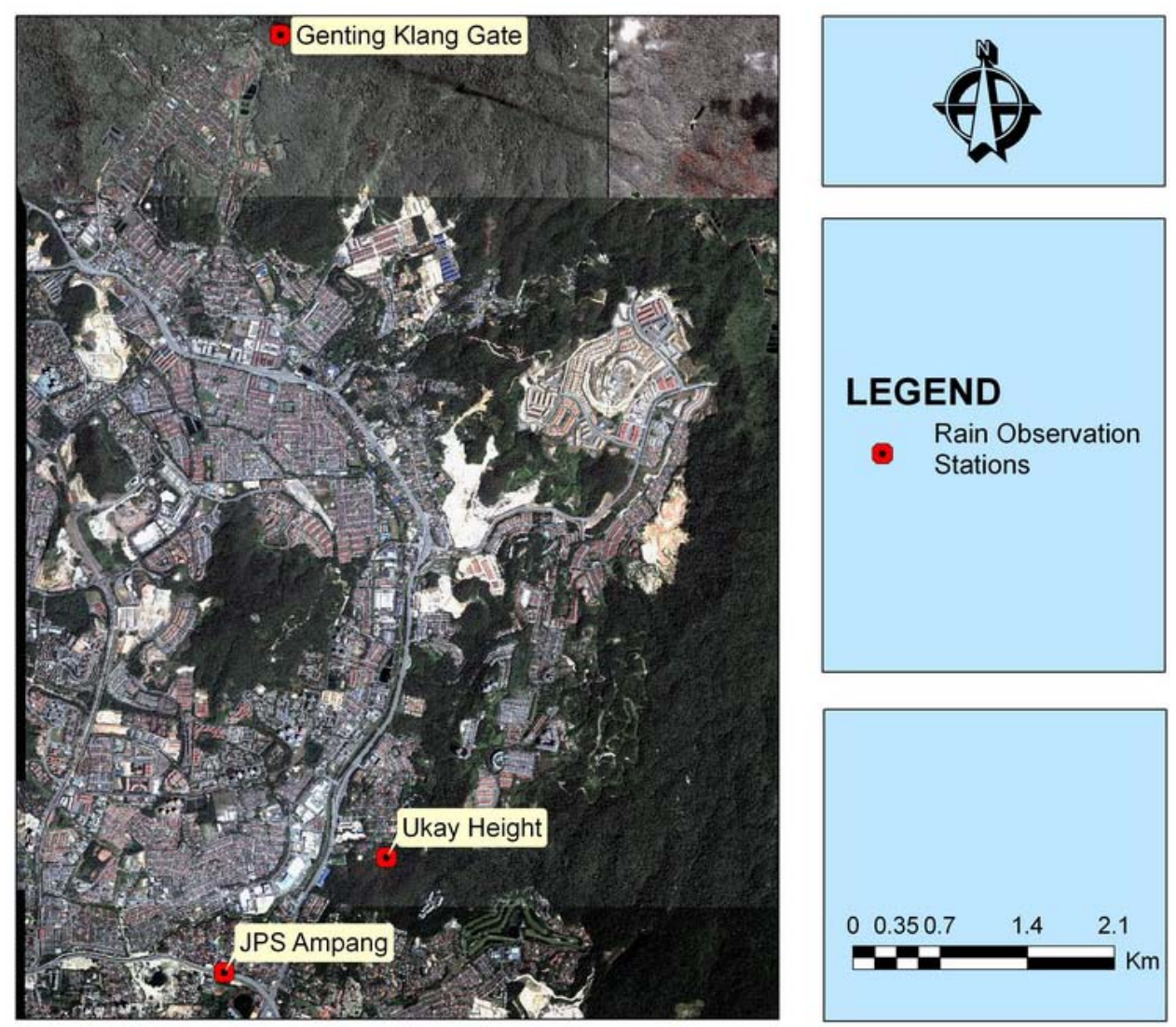

Figure 3 Location of the rain observation stations. 
Table 8 Maximum daily precipitation data.

\begin{tabular}{lcccccc}
\cline { 2 - 6 } & \multicolumn{7}{c}{ Maximum Daily Precipitation (mm) } \\
\cline { 2 - 7 } & $\mathbf{2 0 0 4}$ & $\mathbf{2 0 0 5}$ & $\mathbf{2 0 0 6}$ & $\mathbf{2 0 0 7}$ & $\mathbf{2 0 0 8}$ & Average \\
\hline Genting Klang Station & 105.5 & 101.0 & 145.0 & 138.5 & 98.5 & 117.7 \\
JPS Ampang Station & 75.0 & 102.0 & 116.5 & 96.5 & 107.5 & 99.5 \\
Ukay Height Station & 98.0 & 100.0 & 83.0 & 98.0 & 119 & 99.6 \\
\hline & Sources: JPS Ampang Branch
\end{tabular}

Those areas covered by the station radius receive score value based on average maximum rainfall value. For example, a score of 1.0 will be given to the area that received 40 - $100 \mathrm{~mm}$ rainfall per day, as illustrated in Table 9.

Table 9 Classification and score division for parameter of maximum daily precipitation.

\begin{tabular}{cc}
\hline Maximum Daily Precipitation (mm) \\
\hline Range & Score \\
\hline $0-40$ & 0.8 \\
$40-100$ & 1.0 \\
$100-200$ & 1.2 \\
$200-300$ & 1.4 \\
$>300$ & 1.6 \\
\hline
\end{tabular}

\subsection{Surface Cover}

There are 4 types of surface cover parameter that suit with this study; thick forest, woodland (shrub), agricultural land, paved land (developed). Based on Table 10, a score value of 2.00 has been determined for parameter of paved land (developed surface). It is because the land tends to be more risky than other types of land.

Table 10 Classification and score division for parameter of surface cover.

\begin{tabular}{cc}
\hline Surface cover & Score \\
\hline Thick forest & 0.20 \\
Woodland (shrub) & 0.50 \\
Agricultural land & 1.00 \\
Paved land (developed) & 2.00 \\
\hline
\end{tabular}




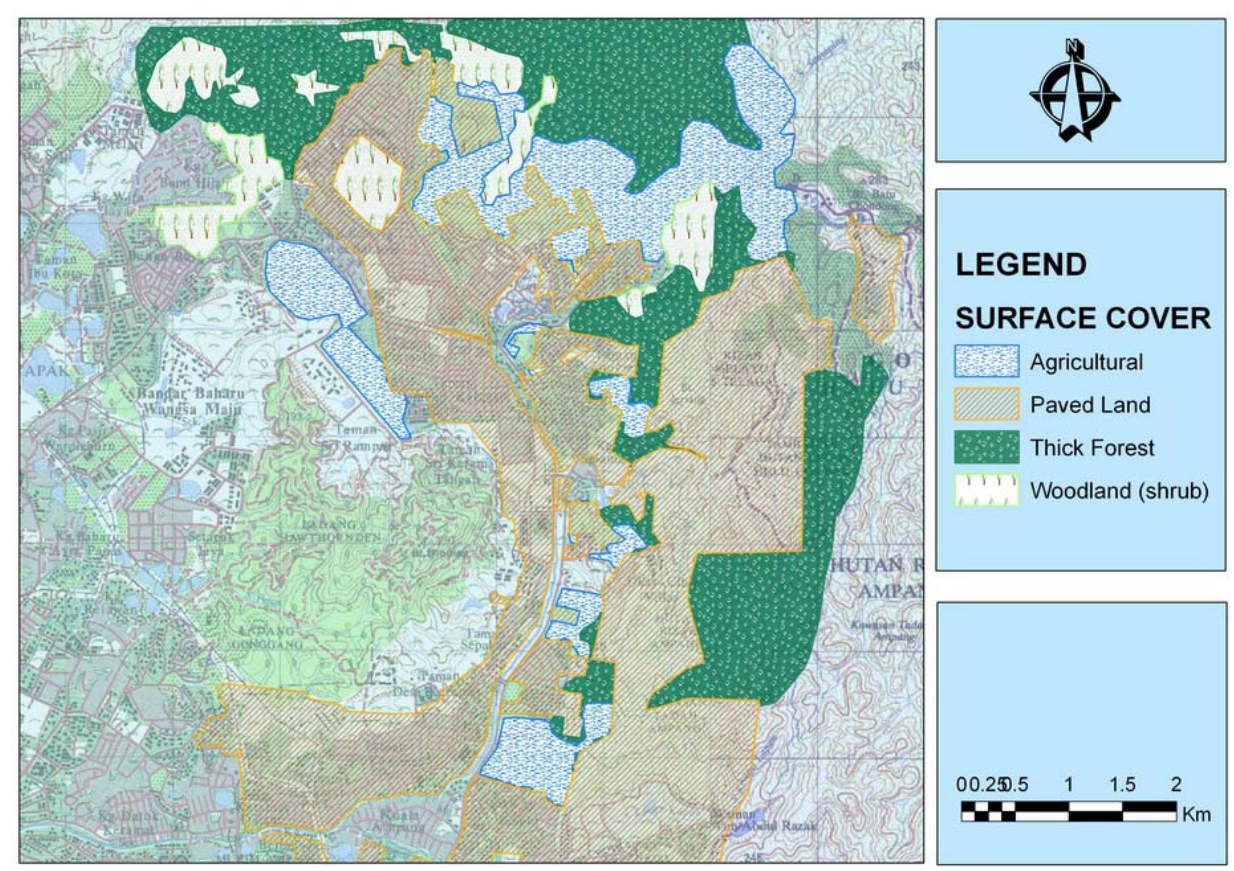

Figure 4 Parameter of surface cover.

\section{$4 \quad$ Result}

From the parameter analysis, using the Raster Calculator that included in ArcGIS 9.3 can produce the hazard map of landslide area (Figure 5). The raster data model represents features as a matrix of cells in continuous space. Each layer represents one attribute (although other attributes can be attached to a cell). Most analysis occurs by combining the layers to create new layers with new cell values. The overlapping of hazard map layers process will produce a final total score value.

To calculate the landslide score, each parameter was summed to the training area as in Eq. 2. The landslide hazard value represents the relative hazard to landslide occurrence. The greatest of landslide score resulted, the higher the hazard to landslide occurrence and the lower landslide score, the lower the hazard to landslide occurrence. The landslide hazard map was made using the landslide score and for interpretation is shown in Fig. 6. Using Eq. 2 the possibilities of landslide occurrence were calculated. On top of this possibility, landslide hazard map was made. Eleven locations of landslide event occurred from 1993 to 2008 were used to validate the landslide hazard analysis. Figure 6 shows that landslide events almost match with the highest value of landslide 
score. Figure 7 shows the potential location through Quickbird-II satellite image view.

\begin{tabular}{|c|c|c|c|c|c|c|c|c|}
\hline \multicolumn{3}{|c|}{$\begin{array}{l}\text { Input raster } \\
\text { inlayer } 1\end{array}$} & \multicolumn{3}{|c|}{$\begin{array}{l}\text { Input raster } \\
\text { inlayer2 }\end{array}$} & \multicolumn{3}{|c|}{$\begin{array}{c}\text { Output raster } \\
\text { (mean of inlayer } 1 \text { and ir }\end{array}$} \\
\hline 1 & 1 & 0 & 1 & 2 & 0 & 1.0 & 1.5 & 0.0 \\
\hline \multirow[t]{2}{*}{2} & 3 & 3 & 2 & 3 & 3 & 2.0 & 3.0 & 3.0 \\
\hline & 0 & 1 & 1 & 1 & 1 & & 0.5 & 1.0 \\
\hline
\end{tabular}

Figure 5 Calculation example from Raster Calculator.
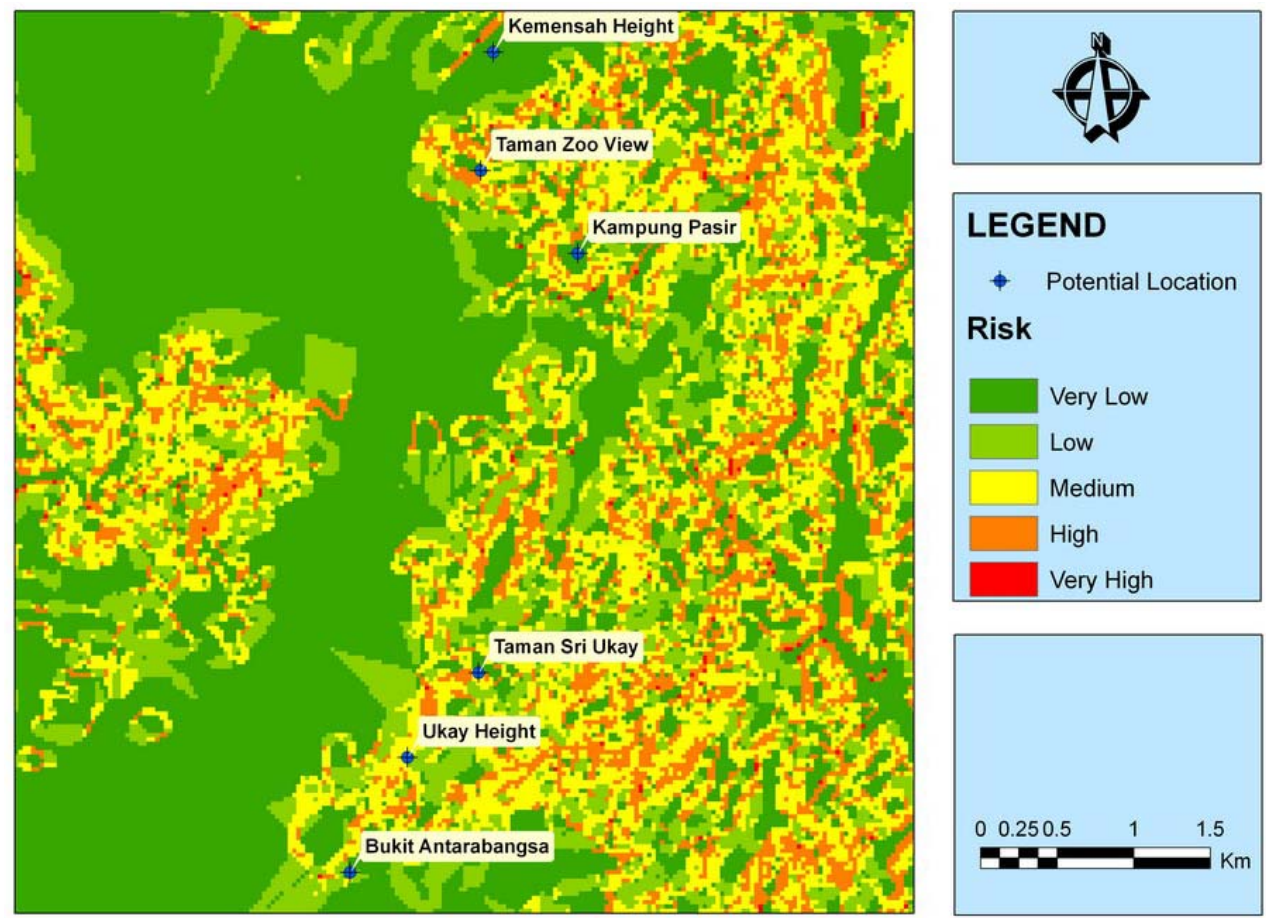

Figure 6 End result of landslide risk analysis.

Table 11 shows parameters that were used to analyze the potential landslide in Ulu Klang area. Landslide event in the area dominantly occurred in quite steep area with slope gradient from 35 o to 60o. While for the geology type the landslide occurred on intrusive acid area more frequently than those of nonintrusive acid area. 
Table 11 Parameter analysis for the risky area.

\begin{tabular}{|c|c|c|c|c|}
\hline \multirow{2}{*}{ Location } & \multirow{2}{*}{ Coordinate } & \multicolumn{2}{|c|}{ Parameter } & \multirow{2}{*}{$\begin{array}{l}\text { Parameter } \\
\text { (Dominant) }\end{array}$} \\
\hline & & Parameter & Details & \\
\hline \multirow[t]{5}{*}{ Bkt. Antarabangsa } & $101^{\circ} 45^{\prime} 33.392^{\prime \prime E}$ & Gradient & $35^{\circ}-60^{\circ}$ & \\
\hline & $3^{\circ} 9^{\prime} 58.97 " \mathrm{~N}$ & Surface cover & paved & \\
\hline & & Geology & intrusive acid & Gradient \\
\hline & & Precipitation & $0 \mathrm{~mm}-100 \mathrm{~mm}$ & \\
\hline & & Height & $100 m-150 m$ & \\
\hline \multirow[t]{5}{*}{ Ukay Height } & $101^{\circ} 45^{\prime} 45.481^{\prime \prime} \mathrm{E}$ & Gradient & $35^{\circ}-60^{\circ}$ & \\
\hline & $3^{\circ} 10^{\prime} 23.436 " \mathrm{~N}$ & Surface cover & agriculture & \\
\hline & & Geology & intrusive acid & Gradient \\
\hline & & Precipitation & $0 \mathrm{~mm}-100 \mathrm{~mm}$ & \\
\hline & & Height & $100 m-150 m$ & \\
\hline \multirow[t]{5}{*}{ Tmn. Sri Ukay } & $101^{\circ} 46^{\prime} 0.497 " \mathrm{E}$ & Gradient & $35^{\circ}-60^{\circ}$ & \\
\hline & $3^{\circ} 10^{\prime} 41.484 " \mathrm{~N}$ & Surface cover & forest & \\
\hline & & Geology & intrusive acid & Gradient \\
\hline & & Precipitation & $0 \mathrm{~mm}-100 \mathrm{~mm}$ & \\
\hline & & Height & $100 m-150 m$ & \\
\hline \multirow[t]{5}{*}{ Kampung Pasir } & $101^{\circ} 46^{\prime} 21.305^{\prime \prime E}$ & Gradient & $35^{\circ}-60^{\circ}$ & \\
\hline & $3^{\circ} 12^{\prime} 10.748 " \mathrm{~N}$ & Surface cover & paved & \\
\hline & & Geology & $\begin{array}{l}\text { non-intrusive } \\
\text { acid }\end{array}$ & Gradient \\
\hline & & Precipitation & $100 \mathrm{~mm}-118 \mathrm{~mm}$ & \\
\hline & & Height & $150 m-200 m$ & \\
\hline \multirow[t]{5}{*}{ Tmn. Zoo View } & $101^{\circ} 46^{\prime} 0.694^{\prime \prime E}$ & Gradient & $35^{\circ}-60^{\circ}$ & \\
\hline & $3^{\circ} 12^{\prime} 28.28 " \mathrm{~N}$ & Surface cover & forest & \\
\hline & & Geology & $\begin{array}{l}\text { non-intrusive } \\
\text { acid }\end{array}$ & Gradient \\
\hline & & Precipitation & $100 \mathrm{~mm}-118 \mathrm{~mm}$ & \\
\hline & & Height & $100 m-150 m$ & \\
\hline \multirow[t]{5}{*}{ Kemensah Height } & 10146'3.323"E & Gradient & $35^{\circ}-60^{\circ}$ & \\
\hline & $3^{\circ} 12^{\prime} 53.492 " \mathrm{~N}$ & Surface cover & paved & \\
\hline & & Geology & intrusive acid & Gradient \\
\hline & & Precipitation & $100 \mathrm{~mm}-118 \mathrm{~mm}$ & \\
\hline & & Height & $56 m-100 m$ & \\
\hline
\end{tabular}



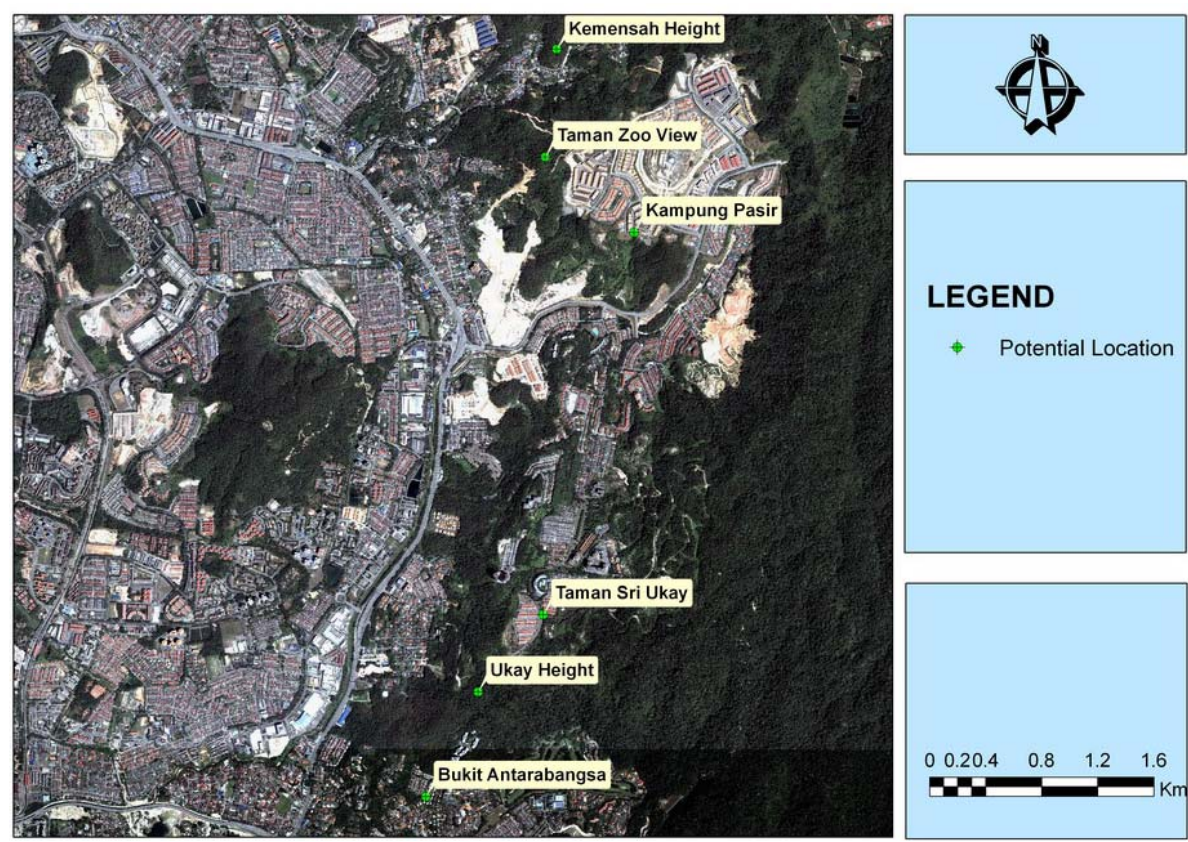

Figure 7 The location of the potential location through satellite image view.

\section{$5 \quad$ Conclusion}

Landslides are among the most hazardous of natural disasters. Government and research institutions worldwide have attempted for years to assess landslide hazards and risks, and to show their spatial distribution. Landslide susceptibility maps have been constructed using the relationship between each landslide and causal factors. In this study, a prediction approach to estimate susceptible areas to landslides using GIS is presented for Ulu Klang area. The result showed that the model was very suitable in predicting landslide hazard and generating landslide hazard maps. These results can be used as basic data to assist slope management and land-use planning.

\section{References}

[1] Abdullah, C. H. \& Mohamed, A., Landslide and National Slope Policy, Seminar on Safe Hill- Site Development, Malaysia, February 14, 2009

[2] Lee, S., \& Talib, J.A., Probabilistic landslide susceptibility and factor effect analysis, Environmental Geology, 47, pp. 982-990, 2005.

[3] Lee, S., \& Pradhan, B., Landslide hazard mapping at Selangor, Malaysia using frequency ratio and logistic regression models, Landslides 4, pp. 33-41, 2006. 
[4] Huat, L. T., Othman, M. A., Mohamad, A., Shaharom, S., Mahmud, M., \& Baba, M. F. Area Based Slope Hazard Assessment and Mapping in Hulu Klang-Ampang, International Conference on Slope Malaysia, Kuala Lumpur 4-6 November 2008, pp. 409-420, 2008.

[5] Hutchinson, C.F., \& Toledano, J., Guidelines for demonstrating geographical Information systems based on participatory development, International Journal of Geographical Information Systems, 7(5), pp. 453-461, 1993.

[6] Golder and Associates, Report on Stage 2A Study Landslide Hazard \& Risk Assessment for Currumbin Hill Gold Coast, pp. 1-53, 2006.

[7] Singh, H., Huat, B. K., \& Jamaludin, S., Slope Assessment: A Review and Evaluation of Current Techniques Used for Cut Slopes in the Mountainous Terrain of West Malaysia, EJGE, 13, 2008. 